\title{
“RELATIVE MOVEMENTS OF REAL WAGES AND OUTPUT"-HOW DOES KEYNES'S 1939 ESSAY RELATE TO HIS THEORY OF EFFECTIVE DEMAND?
}

BY

\author{
JOCHEN HARTWIG
}

\begin{abstract}
John Maynard Keynes's essay "Relative Movements of Real Wages and Output" is widely believed to be an important amendment to his General Theory because, in this essay, Keynes relaxed his core assumption of decreasing marginal returns to labor. I discuss the reasons that prompted Keynes to do so and then examine the consequences of replacing decreasing with non-decreasing returns for the model of effective demand from chapter 3 of the General Theory. I conclude that non-decreasing marginal returns do not sit comfortably with the principle of effective demand. The view that Keynes's 1939 essay constitutes an important amendment to his General Theory has thus to be put into perspective.
\end{abstract}

\section{INTRODUCTION}

In The Collected Writings of John Maynard Keynes, the seminal General Theory of Employment, Interest and Money is volume 7. The difference between volume 7 and the original edition is that three appendices accompany the main text. Appendix 1 lists the printing errors in the first edition of the General Theory corrected for in volume 7. Appendix 2 also contains corrections to the General Theory, which Keynes published

\footnotetext{
Jochen Hartwig, Chemnitz University of Technology, Faculty of Economics and Business Administration, Thüringer Weg 7, 09107 Chemnitz, Germany, and ETH Zurich, KOF Swiss Economic Institute, Leonhardstrasse 21, 8092 Zurich, Switzerland. A discussion with Till van Treeck about the significance of the assumption of decreasing marginal returns for Keynes's theoretical edifice prompted me to write this essay. I would like to thank William A. Darity Jr. for his excellent comments on earlier versions of this paper as well as the reviewers of this journal for their valuable insights. All remaining errors are mine.
} 
in the September 1936 issue of the Economic Journal as "Fluctuations in Net Investment in the United States" after Simon Kuznets had pointed out some errors in Keynes's use of statistics that Kuznets had generated. Appendix 3 is Keynes's March 1939 Economic Journal article, "Relative Movements of Real Wages and Output." Obviously, this article had been chosen for inclusion in volume 7 because the editors of the Collected Writings believed that it also amended-if not corrected-the General Theory in a significant way.

In "Relative Movements of Real Wages and Output," Keynes discusses various issues, one of which is of prime importance and will therefore be the sole focus of this paper. Keynes relaxes a core assumption he thoroughly relies on in the General Theory: the assumption of decreasing marginal returns to labor in the short period. Why is this important?

First of all, this assumption was very dear to Keynes. Only two years before "Relative Movements of Real Wages and Output" appeared in print, he had written to Bertil Ohlin: "I have always regarded decreasing physical returns in the short period as one of the very few incontrovertible propositions of our miserable subject!" (Keynes [1937] 1973, p. 190). In the General Theory, Keynes relies on the assumption of decreasing physical returns, especially at the beginning of the book. In chapter 2, for instance, Keynes reconstructs what he calls 'classical economics' in terms of two postulates. The 'first classical postulate' states, "The wage is equal to the marginal product of labour" (Keynes 1936, p. 5). Keynes should have added: "and the marginal product of labour is decreasing in the short period." He makes this amendment further down in chapter $2{ }^{1}$

So the conclusion is that real wages and output move in opposite directions. In the General Theory, Keynes even conjectures that "a statistical enquiry" would confirm this (Keynes 1936, pp. 9-10). Three years later, however, such statistical enquiries had been carried out (by Dunlop 1938; and Tarshis 1938, 1939), and their results failed to confirm Keynes's conjecture. This prompted Keynes to write the essay "Relative Movements of Real Wages and Output," in which he suggests that - contrary to what is assumed in the General Theory - marginal returns may be non-decreasing over parts of the output range.

Keynes does not seem to have believed that this concession hurts his theory or his policy recommendations in any way. On the contrary, he writes: "If the falling tendency of real wages in periods of rising demand is denied, ... it would be possible to simplify considerably the more complicated version of my fundamental explanation which I have expounded in my 'General Theory.' My practical conclusions would have, in that case, à fortiori force" (Keynes 1939, pp. 40-41). ${ }^{2}$

\footnotetext{
1" [W]ith a given organisation, equipment and technique, real wages and the volume of output (and hence of employment) are uniquely correlated, so that, in general, an increase in employment can only occur to the accompaniment of a decline in the rate of real wages... This is simply the obverse of the familiar proposition that industry is normally working subject to decreasing returns in the short period during which equipment etc. is assumed to be constant; so that the marginal product in the wage-good industries (which governs real wages) necessarily diminishes as employment is increased. So long, indeed, as this proposition holds, any means of increasing employment must lead at the same time to a diminution of the marginal product and hence of the rate of wages measured in terms of this product" (Keynes 1936, pp. 17-18). ${ }^{2}$ Keynes attaches a footnote to the first sentence in the quote, which states that especially chapter 2 of the General Theory could be simplified and needs to be revised in the light of the new evidence.
} 
My aim in this paper is to probe this claim, and to contribute to the literature asking what the replacement of decreasing with non-decreasing physical returns in the short period implies for the models advanced in the General Theory. Claudio Sardoni (1994a), for instance, shows that the theory of income distribution implicit in the General Theory loses its generality under non-decreasing returns, and Sardoni (1994b) discusses two additional consequences. First, non-decreasing returns would have forced Keynes to drop his notion of perfect (or free) competition because if short-period returns are constant, firms facing downward-sloping demand curves-i.e., operating under imperfect competition-must be assumed in order to establish an equilibrium. Second, Keynes's theory of investment also hinges on the assumption of decreasing returns because decreasing returns result in prices for investment goods rising with output so that the marginal efficiency of capital declines. Without this mechanism, firms would - at least in the short period-want to push investment to the fullemployment level. ${ }^{3}$

In this paper, I intend to examine the consequences of replacing decreasing with non-decreasing returns for one specific model from the General Theory: the model of effective demand from chapter 3 . To this end, the next section will start out by explaining the chapter 3 model, highlighting the role of decreasing marginal returns in it. ${ }^{4}$ Section III then discusses the backlash against decreasing marginal returns to labor in 1938-39. What was the critique of John Dunlop and Lorie Tarshis based on, and how did Keynes react? It will be seen that although Keynes did not accept the critique wholeheartedly, he moved some way into accepting the possibility of non-decreasing returns, mainly on empirical grounds.

Section IV revisits the model of effective demand from chapter 3 of the General Theory, asking how it behaves under the assumption of non-decreasing returns. It will be shown that the model fails to produce meaningful results under this assumption. Fortunately, as will be shown in section $\mathrm{V}$, the empirical evidence on real wages moving procyclically with output that lured Keynes into accepting non-decreasing returns is ambiguous; and even if it was valid, it can be shown to be compatible with thoroughly decreasing marginal returns to labor. The last section concludes.

\section{KEYNES'S MODEL OF EFFECTIVE DEMAND}

In chapter 3 of the General Theory, Keynes develops the principle of effective demand in the context of a thought experiment by entrepreneurs, who aim at maximizing profit. To understand the principle, it is important to visualize the economic process as a sequence of production periods. Entrepreneurs plan for a certain period of the future, and are bound by their decisions until the end of the period. The principle of effective demand is what guides their planning. To simplify the exposition, let us assume that the individual plans can be aggregated straightforwardly and that the planning period is the same for all entrepreneurs.

\footnotetext{
${ }^{3}$ In the long period, it is rather the fall in the prospective yield due to capital becoming less scarce that puts a downward pressure on the marginal efficiency of capital (see Keynes 1936, pp. 136, 213).

${ }^{4}$ Note that the interpretation of the chapter 3 model is contested in the literature. It is not the purpose of this paper, however, to review this controversy (see Hartwig 2007 instead).
} 
Keynes models the entrepreneurs' planning task in terms of two functions: the aggregate supply function (Z), and the aggregate demand function (D). Function $\mathrm{Z}$ is "the aggregate supply price of the output from employing $\mathrm{N}$ men" (Keynes 1936, p. 25). The aggregate supply price is defined by Keynes as "the expectation of proceeds which will just make it worth the while of the entrepreneur to give that employment" (Keynes 1936, p. 24).

Keynes defines $\mathrm{Z}$ as the product of an aggregate price and output component. The latter, the 'output of $\mathrm{N}$ men,' we can identify as net value added ${ }^{5}$ (which is dependent on employment). I chose the symbol $\mathrm{Y}(\mathrm{N})$ for this component. The price level implicit in Keynes's aggregate supply function, $\mathrm{P}^{\mathrm{s}}$, must have the property that the proceeds it generates "will just make it worth the while of the entrepreneurs to give that employment"-in other words, $\mathrm{P}^{\mathrm{s}}$ must be the profit-maximizing price level. With respect to the microfoundations of aggregate supply, the General Theory does not part company with the (neo)classical approach. Therefore, Keynes (1936, pp. 24-25) takes it for granted that the "entrepreneurs will endeavour to fix the amount of employment at the level which they expect to maximise the excess of proceeds over the factor cost."

The mathematical approach to find out that level is standard. Simply differentiate the profit function with respect to employment to obtain the first-order condition. From this, the profit-maximizing supply-price level $\mathrm{P}^{\mathrm{s}}$ can be derived (see equations 1 and 2). ${ }^{6}$

$$
\begin{gathered}
\Pi=P^{s} \cdot Y(N)-w \cdot N \\
\frac{d \Pi}{d N} \stackrel{!}{=} 0 \Rightarrow P^{s} \cdot \frac{d Y}{d N}-w=0 \Rightarrow P^{s}=w \cdot \frac{d N}{d Y}
\end{gathered}
$$

$\mathrm{Z}$, being the mathematical product of the output and the supply price levels, is thus given by (3):

$$
Z=P^{s} \cdot Y(N)=w \cdot \frac{d N}{d Y} \cdot Y(N)
$$

Under decreasing marginal returns to labor, $\mathrm{P}^{\mathrm{s}}$ grows progressively, while $\mathrm{Y}(\mathrm{N})$ grows with diminishing returns. Altogether, $\mathrm{Z}$ might be a linear function of $\mathrm{N}$. At least, this seems to be hinted at in a somewhat opaque footnote on pages 55-56 of the General Theory, in which Keynes suggests two arguably inconsistent things: first, that $\mathrm{Z}$ is linear with a slope of 1 , and second, that the slope of $\mathrm{Z}$ is given by the reciprocal of the money wage. Gerhard Michael Ambrosi (2011) has recently shown that the second proposition could be made sense of if the word 'share' was added at the very end. In other words, Ambrosi argues that the slope of $\mathrm{Z}$ is given by the inverse of the money wage share. Jochen Hartwig (2011) confirms this, showing in a general way that the

\footnotetext{
${ }^{5}$ Not 'gross value added' because Keynes subtracts what he calls 'user cost' - the sum of intermediate consumption and depreciation allowances-from gross output in the aggregate (see Keynes 1936, pp. 23-24).

${ }^{6}$ With $\Pi=$ aggregate profit, $\mathrm{P}^{\mathrm{s}}=$ aggregate supply price level, $\mathrm{Y}=$ net value added, $\mathrm{N}=$ employment, $\mathrm{w}=$ wage unit (equals the average nominal wage rate; see Keynes 1936, p. 41).
} 
slope of $\mathrm{Z}$ is given by the inverse of the output elasticity (which is identical to the money wage share for the standard neoclassical production function that Keynes subscribed to). ${ }^{7}$

Now let us turn to the aggregate demand function D. According to Keynes, it gives "the proceeds which entrepreneurs expect to receive from the employment of $\mathrm{N}$ men" (Keynes 1936, p. 25). In a diagram with employment as abscissa and expected proceeds as ordinate, which Keynes describes verbally on page 25 of the General Theory, $\mathrm{D}$ lies above $\mathrm{Z}$ for small $\mathrm{N}$. At a certain point-corresponding to a certain level of employment $\mathrm{N}$-however, $\mathrm{D}$ and $\mathrm{Z}$ intersect. Keynes calls this point of intersection 'effective demand' and states that 'it is at this point that the entrepreneurs' expectation of profits will be maximised" (Keynes 1936, p. 25).

The interpretation of this passage of the General Theory is straightforward if we remember that Keynes adopted the (neo)classical micro-assumptions of profit maximization and price taking. ${ }^{8}$ Because entrepreneurs cannot hope to dictate prices, neither in their individual markets nor at the aggregate level, they use the calculus of equations (1) and (2) to find out which price level would maximize profits. In a way, $\mathrm{P}^{\mathrm{s}}$, the price level implicit in $\mathrm{Z}$, is purely hypothetical. If , for a certain $\mathrm{N}_{1}$, the entrepreneurs expected the price level given by (2) to rule in the market, they would employ $\mathrm{N}_{1}$ men, because they knew that profits would thereby be maximized. But which price level do they really expect? This question is not answered by the supply function at all, but by the demand function. The price level implicit in $\mathrm{D}$, which we can call the demand price level $\mathrm{P}^{\mathrm{d}}$, is the price level the entrepreneurs really expect to rule in the market. Hence, Keynes writes, "let D be the proceeds which entrepreneurs expect to receive from the employment of $\mathrm{N}$ men." If, for a certain $\mathrm{N}, \mathrm{P}^{\mathrm{d}}>\mathrm{P}^{\mathrm{s}}$, "there will be an incentive to entrepreneurs to increase employment beyond $\mathrm{N}$ and, if necessary, to raise costs by competing with one another for the factors of production, up to the value of $\mathrm{N}$ for which Z has become equal to D" (Keynes 1936, p. 25).

Figure 1 illustrates the D/Z model for a simple production function with labor as the only production factor exhibiting decreasing marginal returns. I chose the function $\mathrm{Y}=\mathrm{N}^{0.7}$. Normalizing the nominal wage rate to 1 gives us a supply price of $\mathrm{P}^{\mathrm{s}}=1 / 0.7 * \mathrm{~N}^{0.3}$ (see equation 2 above). Equation 3 tells us that $\mathrm{Z}$ is given by $\mathrm{Z}=1 / 0.7 * \mathrm{~N}^{0.3} * \mathrm{~N}^{0.7}=1 / 0.7 * \mathrm{~N} .{ }^{9}$ For D, I assume that the entrepreneurs expect

\footnotetext{
${ }^{7}$ Unfortunately, the exposition in Hartwig (2011) is tainted with printing errors in the formulas. See the Working Paper version (KOF Working Paper No. 282) at www.kof.ethz.ch instead (accessed 27 December 2016).

${ }^{8}$ Keynes's notion of price taking departs from the strict microeconomic theory of the small firm operating under perfect competition. That theory would not allow for entrepreneurs forming ex ante expectations about demand. Keynes — who was concerned with the real world — did not have such firms in mind, however. In his theory, firms are not 'atomistic,' but also not powerful enough to dictate the price. They have to form expectations about the price for their products the market will accept and about the market share that might be attributable to them (see Chick 1992).

${ }^{9}$ Note that the slope of $\mathrm{Z}$ equals the inverse of the output elasticity $\alpha$, which corroborates the theoretical analysis in Hartwig (2011). The normalization of the money wage rate to 1 is irrelevant in this context because in the footnote on pp. 55-56 of the General Theory, Keynes describes the slope of Z in wage units; i.e., of $Z / w$ (or $Z_{w}$ in the notation of the General Theory). Hartwig (2011) shows that the slope of $Z_{w}$ is equal to the inverse of the output elasticity; i.e., equal to $1 / \alpha$. So the slope of $Z$ is equal to w/ $\alpha$. Because of the normalization of the money wage rate to 1 , we have the special case that the slope of $Z$ is the same as that of $Z_{w}$.
} 




Figure 1. Simulated $\mathrm{D}$ and $\mathrm{Z}$ functions for $\mathrm{Y}(\mathrm{N})=\mathrm{N}^{0.7}$.

a demand price level of 5 so that the function for $\mathrm{D}$ is given by $\mathrm{D}=5 * \mathrm{~N}^{0.7}$. Employment at the abscissa runs from 1 to 70 . Functions D and $\mathrm{Z}$ intersect at an employment level between 65 and 66. At this employment level, the marginal product of labor $\left(\mathrm{MPL}=0.7 * \mathrm{~N}^{-0.3}\right)$ lies between 0.200 and 0.199 , which is equal to the real wage for the assumed values $\mathrm{w}=1, \mathrm{P}^{\mathrm{d}}=5$.

Higher demand price expectations move the D curve upward and lead to a $D / Z$ equilibrium with higher employment, a lower MPL, and a lower real wage. This does not imply at all, however, that Keynes's acceptance of the 'first classical postulate' also indicated his acceptance of classical labor market theory. It is not the case that a lower real wage leads to a higher (labor demand and) level of employment. Keynes merely writes that the two magnitudes — real wages and employment-are 'correlated' (see the quote given above in footnote 1). The curve depicting the marginal product of labor is not a labor demand curve (see also Davidson 1983a). The marginal product of labor schedule rather gives the real wage that will be associated ex post with a certain employment level-the latter depending on effective demand.

\section{WHY DID KEYNES RELAX THE ASSUMPTION OF DECREASING MARGINAL RETURNS TO LABOR?}

\section{The Critique by Dunlop and Tarshis}

Dunlop (1938) and Tarshis (1939) criticized Keynes's assumption from the General Theory that real wages and output move in opposite directions, from both an empirical and a theoretical point of view. Both articles focus on the relative movement of real and money wages, not of real wages and output. However, based on Keynes's (1936, p. 10) 
remark that labor would be "readier to accept wage-cuts when employment is falling off," Dunlop (1938, p. 431) attributed to him the view that money wages move procyclically with employment (and output), because in upswings the power of trade unions rises. In this case, the finding of a procyclical movement of real and money wages translates into procyclicality between real wages and output.

At the empirical front, Dunlop concluded from his set of annual British wage data over the period 1860 to 1937 that real and money wages tended to increase together. A fall in the money wage, however, was as likely to be associated with a rise in the real wage as with a decline. Tarshis, drawing on monthly US wage data over the period January 1932 to March 1938, found that real and money wage indices moved in the same direction most of the time. He reports a Yule's coefficient of association of +0.86 .

In terms of theory, Dunlop (1938, pp. 431-433) questions three assumptions Keynes makes (or allegedly makes). First, the assumption that money wages rise in upswings: Dunlop claims that they need not. Second, the assumption that marginal cost curves are rising: Dunlop claims that they may be flat in the presence of excess capacity. Third, the assumption of perfect competition: Dunlop objects that if prices are a function of the 'degree of monopoly,' which declines in upswings, the real wage will concomitantly rise. In addition, Dunlop (1938, p. 433) makes the observation that there are cyclical swings in productivity due to time lags in the introduction of new equipment. These can also impact the nexus between real wages and output (see below in section V).

Tarshis's (1939, p. 153) theoretical objections are very similar to Dunlop's. He criticizes the assumed nexus between money wage raises and the level of unemployment, the assumed positive inclination of marginal cost curves and the assumed constant degree of competition over the cycle. ${ }^{10}$

\section{Keynes's Reaction to the Critique by Dunlop and Tarshis}

Keynes was clearly not upset by Dunlop's and Tarshis's critique. After all, he published their papers in the Economic Journal, which he edited at the time. The supplement volume of the Collected Writings of John Maynard Keynes (vol. 29, pp. 283-288) contains the brief correspondence between Dunlop and Keynes prior to the publication of Dunlop's paper. It consists of three letters by Dunlop and two replies by Keynes. In his first reply, Keynes is concerned with clarifying the stance he took in the General Theory in the light of the statistical material that Dunlop had submitted to him. He confirms that he regarded money wages as a positive function of economic activity, and reaffirms his view as to "the normal prevalence of increasing cost in short-period conditions" (Keynes [1938a] 1979, p. 284). He insists that any statistical investigation of the money-wage-real-wage nexus should deal with data on trend-adjusted hourly wage rates-not aggregate wage earnings. He invites Dunlop to submit a revised version of his paper in which these aspects are accounted for. After having received the revised version, he makes some additional suggestions for improving the exposition, but makes clear from the outset: "I like this article very well in its revised form and shall be glad to accept it for the Economic Journal"

\footnotetext{
${ }^{10}$ Tarshis (1938) already expressed doubts with respect to diminishing returns to increasing employment based on his US dataset.
} 
(Keynes [1938b] 1979, p. 286). There are no hints that Keynes thought Dunlop's results to be incompatible with the General Theory. ${ }^{11}$

On the contrary: as was mentioned in the introduction, Keynes even thought that the new findings would, on the one hand, enable him to simplify his theoretical exposition, and, on the other hand, strengthen his 'practical' (i.e., policy) conclusions. In terms of theory, dropping the generalization of decreasing marginal returns to labor would help avert the 'labor demand curve' misinterpretation of Keynes's acceptance of the 'first classical postulate' mentioned above in section II. ${ }^{12}$ For Keynes, employment rises when effective demand is stimulated and not as a consequence of declining real wages. He distances himself from "Prof. Pigou ... and many other economists" who hold that public investment policies produce

their effect by deceiving, so to speak, the working classes into accepting a lower real wage, effecting by this means the same favourable influence on employment which, according to these economists, would have resulted from a more direct attack on real wages. ... If the falling tendency of real wages in periods of rising demand is denied, this alternative explanation must, of course, fall to the ground. (Keynes 1939, p. 40)

The advantage of assuming non-decreasing returns in terms of policy, of course, would be that expansionary policies would no longer automatically lead to inflation, so that "the warnings of the anti-expansionists need cause us less anxiety" (Keynes 1939, p. 41).

These considerations led Keynes to admit for the first time the possibility of nonincreasing marginal real cost. "We should all agree," he writes, "that if we start from a level of output very greatly below capacity, so that even the most efficient plant and labour are only partially employed, marginal real cost may be expected to decline with increasing output, or, at the worst, remain constant" (Keynes 1939, p. 44).

Nevertheless, Keynes remained reluctant to "discard too much of our former conclusions which, subject to the right qualifications, have à priori support and have survived for many years the scrutiny of experience and common sense" (Keynes 1939 , p. 41). In particular, he remained unconvinced by most of the theoretical objections by Dunlop (1938) and Tarshis (1939), which had previously been made by Ohlin ([1937] 1973).

Vivienne Brown (1991) has carefully studied this theoretical debate over the nature of marginal returns. She argues that it was Keynes's "unrecognized use of a concept of marginal productivity which was different from theirs" (Brown 1991, p. 440) that explains most of the disagreement between him and his critics. For Keynes, diminishing marginal returns were the result of factors of production being non-homogeneous (Keynes 1936, p. 296). This means that they result from the most efficient worker and piece of equipment being employed first, followed by the second-most efficient and so on. The traditional view, on the other hand, to which his critics adhered, was that diminishing returns result from a homogeneous variable factor (labor) being increasingly applied to a likewise homogeneous fixed factor (capital). Based on their notion

${ }^{11}$ I found no correspondence in the Collected Writings on Tarshis's (1939) note, which appeared in print in the same issue of the Economic Journal as Keynes's (1939) reply.

${ }^{12} \mathrm{~A}$ modern representation of this misinterpretation, I would argue, is provided by Meltzer (1983). See also Davidson (1983b). 
of excess capacity as a less intensive use of the fixed factor, the critics argued against Keynes that the assumption of diminishing marginal productivity was invalid in the presence of excess capacity. They overlooked the fact that, based on Keynes'sunconventional-notion of excess capacity as idle capacity, diminishing returns were possible even in the presence of excess capacity. Hence, neither the theoretical objections against diminishing returns nor the argument made by Dunlop (1938), Tarshis (1939), and Ohlin ([1937] 1973) against his assumption of perfect competition made much impression on Keynes (see Brown 1991, p. 443). His critics had to drop perfect competition because they needed downward-sloping demand curves facing firms as soon as marginal cost curves were no longer upward sloping. Keynes, on the other hand, did not have to assume downward-sloping demand curves because, for him, marginal cost curves were still upward sloping, except under special circumstances.

So if, for Keynes, decreasing marginal returns result from the most efficient worker and piece of equipment being employed first, followed by the second-most efficient and so on, how could he admit at all that marginal returns might be non-decreasing, as he did in "Relative Movements of Real Wages and Output"? A careful reading yields the answer. Keynes contemplates a situation in which "even the most efficient plant and labour are only partially employed" (see above). This suggests that, for the sake of the argument, Keynes suspended marginalism. If labor and plants cannot be increased or reduced marginally, there may be a batch or vintage of equipment and labor of the highest efficiency. If even this best vintage is only partially employed, constant or increasing returns ensue. Even though Keynes did not consider such a situation to be very relevant in practice (see the next section), the empirical evidence put forward by Dunlop and Tarshis — rather than their theoretical arguments-induced him to concede that such a situation can occur. ${ }^{13}$

In the remainder of this paper, I will investigate the consequences of this concession for Keynes's model of effective demand.

\section{NON-DECREASING RETURNS IN THE MODEL OF EFFECTIVE DEMAND}

How does the model of effective demand cope with non-decreasing marginal returns to labor? In "Relative Movements of Real Wages and Output," Keynes suggests a nexus between marginal returns and capacity utilization. Subsequent to the quote given in the previous section, in which he concedes the possibility of constant or declining marginal cost when output is "very greatly below capacity," Keynes points out that "[e]ven if one concedes that the course of the short-period marginal cost curve is downwards in its early reaches, Mr. Kahn's assumption that it eventually turns upwards is,

\footnotetext{
${ }^{13}$ This was a departure from the view he held two years earlier when he wrote to Ohlin: "I should, of course, agree that my proposition ... should have something else substituted for it if constant physical conditions prevailed throughout industry. I should also agree that at the very bottom of the slump one may get rather near this peculiar situation. But in general it never occurred to me that such a situation would exist, and I should have thought there were overwhelming statistics to prove the contrary" (Keynes [1937] 1973, p. 190). This quote again suggests that it was the new 'statistics' that induced Keynes to change his mind.
} 
on general common-sense grounds, surely beyond reasonable question; and that this happens, moreover, on a part of the curve which is highly relevant for practical purposes" (Keynes 1939, pp. 44-45).

Keynes here describes an S-shaped production function. The marginal returns schedule of such a production function is an inverted U. Marginal returns rise when output and employment are low. From some point onwards, however, they begin to decline. Keynes believes that the part of the curve beyond the turning point is "highly relevant for practical purposes." This again reflects his reluctance to give away entirely the "incontrovertible proposition" of decreasing physical returns in the short period in the light of the empirical evidence collected by Dunlop and Tarshis.

To investigate how the $\mathrm{D} / \mathrm{Z}$ model of effective demand copes with an inverted U-shaped marginal returns schedule, I will—as in section II above-specify a concrete functional form for the production function: one that gives rise to a $\mathrm{S}$-shaped curve this time. Assume that the production function is given by $\mathrm{Y}=25 * \mathrm{~N}^{2}-\mathrm{N}^{3} .{ }^{14}$ Still assuming a nominal wage rate equal to 1 , this gives rise to the $\mathrm{Z}$ function $\mathrm{Z}=$ $\left(25 * \mathrm{~N}^{2}-\mathrm{N}^{3}\right) /\left(50 * \mathrm{~N}-3 * \mathrm{~N}^{2}\right)$. For expositional ease, I assume a demand price level equal to $1 / 40$ so that the $\mathrm{D}$ function is given by $\mathrm{D}=\left(25 * \mathrm{~N}^{2}-\mathrm{N}^{3}\right) / 40$. Figure 2 shows the two curves-or, more precisely, the two curves up to the point

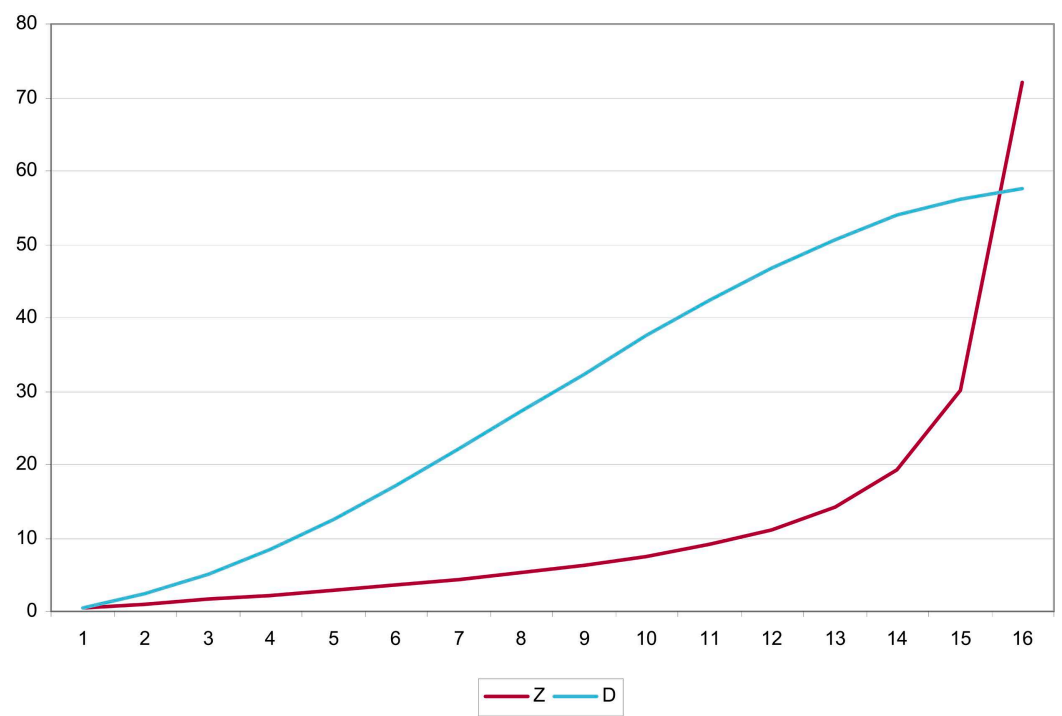

FIGURE 2. Simulated $D$ and $Z$ functions for an S-shaped production function: $Y(N)=25 * N^{2}-N^{3}$.

\footnotetext{
${ }^{14}$ Although Keynes does not suggest that marginal returns are thoroughly increasing or constant, we might ask how the model of effective demand from chapter 3 of the General Theory handles such production functions. In a function with thoroughly increasing returns (e.g., $\mathrm{Y}=\mathrm{N}^{2}$ ), $\mathrm{Z}$ remains a linear function of employment with the slope given by the inverse of the output elasticity; and D remains the product of the demand price level and output. Clearly, D lies above $\mathrm{Z}$ for all $\mathrm{N}$, and the two curves are driven apart exponentially. There is no point of intersection-in other words: no point of effective demand. The same is true for production functions with thoroughly constant returns. Without such a point of intersection, however, the D/Z model fails to determine the level of output and employment.
} 
where the marginal product is still positive. As Robert Pindyck and Daniel Rubinfeld (1995, p. 172) point out, production past this point "is not technically efficient and therefore is not part of the production function; technical efficiency rules out negative marginal products."

As the figure shows, an S-shaped production function gives rise to a $\mathrm{D}$ curve that is also $\mathrm{S}$-shaped and to a $\mathrm{Z}$ curve that is convex. The curves intersect in the region that Keynes regarded as "highly relevant for practical purposes": namely, in the region of decreasing marginal returns. Most notably, a point of intersection in the region of the employment spectrum for which marginal returns are upward sloping is impossible. This means, however, that the principle of effective demand as a model of entrepreneurial decision making under uncertainty, leading up to a planned level of output and employment for the upcoming production period that entrepreneurs expect to be profit maximizing, cannot produce points of effective demand in the region "of output very greatly below capacity." In other words, if one allows for an S-shaped production function, as Keynes did in his 1939 essay (as opposed to the General Theory), the model of effective demand tells us that entrepreneurs never expect that an "output very greatly below capacity" will be profit maximizing. Hence, remembering that entrepreneurs decide about their output and employment levels ex ante based on the model of effective demand, we have to conclude that a situation with output greatly below capacity will never occur. This conclusion, of course, would be inconsistent with the empirical evidence, especially during the Great Depression.

The argument in this paper is that it is not the model of effective demand that is to be blamed for this inconsistency, but Keynes's concession in his 1939 essay that marginal returns may be increasing over a certain range of output. If we deny this possibility and return to the General Theory's assumption of thoroughly decreasing marginal returns, no such inconsistency emerges. A concave D curve can intersect a linear $\mathrm{Z}$ curve at very low levels of employment (and capacity utilization) if the demand price level is sufficiently low. For instance, if we replace the demand price level of 5 in section II by a demand price level of 2, D would intersect $\mathrm{Z}$ at an employment level, not between 65 and 66 as in Figure 1, but at an employment level between 3 and 4 .

But what about the reason why Keynes dropped the assumption he previously thought to be "incontrovertible" - the assumption of decreasing marginal returns in the short period-in the first place: the empirical evidence collected by Dunlop and Tarshis? The next section argues that the empirical evidence on real wages moving procyclically with output that lured Keynes into accepting non-decreasing returns is ambiguous; and even if the evidence was valid, it can be shown to be compatible with thoroughly decreasing marginal returns to labor.

\section{MUST REAL WAGES MOVE COUNTERCYCLICALLY UNDER DECREASING MARGINAL RETURNS?}

Section III concluded that it was the empirical evidence put forward by Dunlop and Tarshis - rather than their theoretical arguments - that induced Keynes to recognize that marginal returns to labor may be non-decreasing in the short period so that real wages, on the one hand, and money wages and output, on the other hand, might move in the same direction. This section makes two points: first, that the empirical evidence 
is ambiguous, and second, that even if it was not ambiguous, real wages might move procyclically with output despite decreasing marginal returns.

As to the first point, already Tarshis, in a postscript to his note, reports "a rather high negative association" between changes in man-hours and changes in real hourly wages in his data (Tarshis 1939, p. 154; emphasis added). So Keynes's inference in the General Theory that "an increase in employment can only occur to the accompaniment of a decline in the rate of real wages" (Keynes 1936, p. 17) is vindicated by Tarshis's data. ${ }^{15}$ Furthermore, in response to the debate in the Economic Journal, Richard Ruggles (1940) raises a number of methodological objections against Dunlop's and Tarshis's studies. His reanalysis of British and American data reveals no clear-cut relation between real and money wage rates. More recently, economic historian Christopher Hanes has argued that changes in households' consumption bundles affect the cyclical behavior of wages: "Nowadays, real consumption wages are procyclical. They were less procyclical before the Second World War, and they may have been acyclical or even countercyclical before the First World War" (Hanes 1996, p. 837). All said, the empirical evidence is everything but clear.

Still, for the sake of the argument, let us assume that (despite the ambiguity of the empirical evidence) real wages do move procyclically with output. One reason why they might do so was given by Dunlop (1939, p. 433): cyclical swings in labor productivity. Productivity shocks - for instance, due to the introduction of new equipment or thanks to an improved organization of production processes-can be expected to happen frequently, even in the short period to which the empirical evidence that persuaded Keynes to relax his assumption of decreasing marginal returns pertains. In the model of effective demand, a positive productivity shock moves the $\mathrm{Z}$ curve outward. At the same time, the D curve moves upwards because higher productivity means that the same number of workers will produce a higher level of output (income).

Let us assume a positive supply shock that raises the output elasticity from 0.7 to 0.75 , and revisit Figure 1 . It has been pointed out in section II that with the lower output elasticity of 0.7 , the $\mathrm{D}$ and $\mathrm{Z}$ curves intersect at an employment level between 65 and 66. The mean marginal product of labor (real wage) over these two employment levels equals 0.1996 . For the higher output elasticity of 0.75 , on the other hand, the D and Z curves intersect at an employment level between 197 and 198. The mean marginal product of labor (real wage) over these two employment levels equals 0.2001 , which is a little bit higher, not lower. However, for practical purposes, these two values are equal. This is in line with what Keynes believed to be the general case in "Relative Movements of Real Wages and Output."16

\footnotetext{
${ }^{15}$ Keynes (1939, p. 42) notes this. This implies, however, that over the period under inspection, money wages did not move in line with economic activity in the US, which runs counter to Keynes's expectations (see above in section III).

16"If, at the present stage of the inquiry, we are to make any single statistical generalisation, I should prefer one to the effect that, for fluctuations within the range which has been usual in the periods investigated which seldom approach conditions of full employment, short-period changes in real wages are usually so small compared with the changes in other factors that we shall not often go far wrong if we treat real wages as substantially constant in the short period (a very helpful simplification if it is justified). The conclusion, that changes in real wages are not usually an important factor in short-period fluctuations until the point of full employment is approaching, is one which has been already reached by Dr. Kalecki on the basis of his own investigations" (Keynes 1939, pp. 42-43).
} 
The upshot is that finding procyclical movements of real wages in empirical dataor real wages staying constant over the cycle_-is perfectly compatible with decreasing marginal returns to labor in the short period, because even over short periods such as a 'month,' the capital stock and the organization of production processes do not stay constant (as they should according to the theoretical concept of the short period), so that the MPL curve shifts. ${ }^{17}$ Dunlop (1938, p. 433) acknowledged this, stating that " $[p]$ recisely because of changes in organisation, equipment and technique and changes in the degree of monopoly, real and money wage rates have apparently moved together on the upswing." 18

What still has to be pointed out, however, is that, for these reasons, there was no need for Keynes to give away the "incontrovertible proposition" of decreasing marginal returns in the short period.

\section{CONCLUSION}

The aim of this paper is to highlight the importance of the assumption of diminishing marginal returns to labor for Keynes's model of effective demand. Keynes does not seem to have believed that ceding diminishing marginal returns to the critique by Dunlop and Tarshis in his 1939 essay, "Relative Movements of Real Wages and Output," hurts his theory or his policy recommendations in any way. The paper argues that Keynes was wrong in this assessment. Rather, his model of effective demand described in chapter 3 of the General Theory works only under the assumption of decreasing marginal returns; it fails to determine the level of effective demand or produces inconsistent results if this assumption is relaxed or dropped.

Non-decreasing marginal returns to labor are incompatible not only with the model of effective demand, but also with other key aspects of Keynes's theory (see Sardoni 1994a, 1994b); and it is not necessary to assume non-decreasing returns in order to explain procyclical movements of real wages. Therefore, Keynes should not have given away the assumption of decreasing marginal returns in "Relative Movements of Real Wages and Output." The view that this essay constitutes an important amendment to his General Theory thus has to be put into perspective.

\section{REFERENCES}

Ambrosi, Gerhard Michael. 2011. "Keynes' Abominable Z-footnote." Cambridge Journal of Economics 35: 619-633.

Brown, Vivienne. 1991. “On Keynes' Inverse Relation between Real Wages and Employment: A Debate over Excess Capacity." Review of Political Economy 3: 439-465.

\footnotetext{
${ }^{17}$ Darity (1989, pp. 21-22) discusses a number of additional reasons why real wages might move procyclically in spite of decreasing marginal returns, such as expectational errors, time lags, and shifts in the output composition between consumption goods and investment goods.

${ }^{18}$ Ruggles (1940, p. 148) shares the argument, but reaches a different empirical conclusion: "The interrelation of wholesale and retail prices, the degree of monopoly, and the changing economic structure continually interact upon the relationship [between real and money wage rates] and render it unstable."
} 
Chick, Victoria. 1992. “The Small Firm under Uncertainty: A Puzzle of the General Theory.” In Bill Gerrard and John Hillard, eds., The Philosophy and Economics of J. M. Keynes. Aldershot: Edward Elgar, pp. 149-164.

Darity, William A., Jr. 1989. "The Simple Analytics of Aggregate Demand Price and Aggregate Supply Price Analysis.” In Jan A. Kregel, ed., Inflation and Income Distribution in Capitalist Crisis: Essays in Memory of Sidney Weintraub. Houndsmills: Macmillan, pp. 9-24.

Davidson, Paul. 1983a. "The Marginal Product Curve Is Not the Demand Curve for Labor and Lucas's Labor Supply Curve Is Not the Supply Curve for Labor.” Journal of Post Keynesian Economics 6: $105-121$.

—. 1983b. "The Dubious Labor Market Analysis in Meltzer's Restatement of Keynes's Theory." Journal of Economic Literature 21: 52-56.

Dunlop, John T. 1938. "The Movement of Real and Money Wage Rates." Economic Journal 48: 413-434.

Hanes, Christopher. 1996. "Changes in the Cyclical Behavior of Real Wage Rates, 1870-1990.” Journal of Economic History 56: 837-861.

Hartwig, Jochen. 2007. "Keynes vs. the Post Keynesians on the Principle of Effective Demand." European Journal of the History of Economic Thought 14: 725-739.

—. 2011. "Keynes's Aggregate Supply Function: Everything You Always Wanted to Know about Z." International Journal of Applied Economics and Econometrics 19 (Special Issue on John M. Keynes): 63-71.

Keynes, John M. 1936. The General Theory of Employment, Interest, and Money. London: Macmillan.

—. [1937] 1973. Letter to B. Ohlin, 29 April 1937. In Donald E. Moggridge, ed., The Collected Writings of John Maynard Keynes. Volume 14. London: Macmillan, pp. 187-191.

—. [1938a] 1979. Letter to J. T. Dunlop, 9 April 1938. In Donald E. Moggridge, ed., The Collected Writings of John Maynard Keynes. Volume 29. London: Macmillan, pp. 284-285.

—. [1938b] 1979. Letter to John T. Dunlop, 30 May 1938. In Donald E. Moggridge, ed., The Collected Writings of John Maynard Keynes. Volume 29. London: Macmillan, pp. 286-287.

- 1939. "Relative Movements of Real Wages and Output.” Economic Journal 49: 34-51.

Meltzer, Allan H. 1983. "Interpreting Keynes.” Journal of Economic Literature 21: 66-78.

Ohlin, Bertil. [1937] 1973. Addendum: Ohlin's original remarks [on the General Theory]. In Donald E. Moggridge, ed., The Collected Writings of John Maynard Keynes. Volume 14. London: Macmillan, pp. 191-200.

Pindyck, Robert S., and Daniel L. Rubinfeld. 1995. Microeconomics. Third edition. Englewood Cliffs, NJ: Prentice Hall.

Ruggles, Richard. 1940. “The Relative Movements of Real and Money Wage Rates.” Quarterly Journal of Economics 55: 130-149.

Sardoni, Claudio. 1994a. "Effective Demand and Income Distribution in The General Theory." Journal of Income Distribution 3: 48-83.

- 1994b. "The General Theory and the Critique of Decreasing Returns." Journal of the History of Economic Thought 16: 61-85.

Tarshis, Lorie. 1938. "Real Wages in the United States and Great Britain.” Canadian Journal of Economics and Political Science 4: 362-376. 